\title{
The Predictive Role of Values and Perceived Social Support Variables in Marital Adjustment
}

\author{
Abdullah Mert ${ }^{1}$ \\ Department of Psychological Counseling and Guidance, Faculty of Education, Uşak University, Uşak, Turkey
}

Copyright $\bigcirc 2018$ by authors, all rights reserved. Authors agree that this article remains permanently open access under the terms of the Creative Commons Attribution License 4.0 International License

\begin{abstract}
The aim of this study was to examine the predictive role of values and perceived social support variables in marital adjustment level among married individuals. A total of 422 (211 pairs) married individuals who agreed to participate voluntarily were included. The study was conducted in accordance with the relational screening model. "Dyadic Adjustment Scale (SDS)", "Value Scale" and "The Multidimensional Scale of Perceived Social Support (MSPSS)" were used in the study in fulfillment of the aim of the research. Correlation and regression analysis were used in the research. Analyses were tested with the help of SPSS 16.0 package with .01 and .05 levels of significance. The findings of the research showed the presence of predictive role of values and perceived social support variables in marital adjustment. Findings obtained from the study are discussed in relation to literature.
\end{abstract}

Keywords Marital Adjustment, Perceived Social Support, Value

\section{Introduction}

Marriage is an important human relationship in the multifaceted development of individuals and societies [24]. In the marriage process which includes psychological, social, emotional, sexual, economic relations, the endeavor of meeting the needs of the individuals is foregrounded. In addition, this process reveals a number of new experiences that people need to adapt to. The perception of the level of being able to meet the needs of the individual in the marriage [39] and the level of adaptation to the new life is expressed by the concept of marital adjustment [37]. Spanier [36] conceptualizes the concept of marital adjustment as the adaptation of couples to everyday life and changing conditions in this life, and to change each other in a certain time. Marital adjustment is a concept that reflects the nature of the relationship between the couples and expresses the capacities of the spouses to carry on their relations [12]. In a sense, marital adjustment is a structure that reflects how healthy and positive the orientation of marriage is. Marital adjustment has many dynamics in it. It can be argued that this makes it difficult to ground and analyze marital adjustment [30]. Larson [23] found that the level of marital adjustment was depended on personal characteristics (shyness, extreme responsiveness, flexibility, neuroticism, etc.), couple competences (problem solving skills, intimacy, reconciliation, cohesion etc.) and environmental factors (the effects of family background, job stress, traces of family process, sources of environmental stress, and so on.). Besides, Spanier [36] stated that this differentiation is due to problematic situations between spouses, the concerns between spouses, the satisfaction between spouses, the level of commitment of spouses to each other, and the consensus level of spouses in important matters.

Factors such as positive communication between spouses, overcoming problems with positive solutions [29], high satisfaction among couples, high level of commitment between spouses, consensus on important family issues, low level of difference, tension and individual anxiety following marriage, activities that are enjoyed together [36] can be expressed as the main determinants of the formation of a healthy marriage structure. Marital adjustment that including the perception of the fulfillment level at circumstances emerged after marriage [1]; [26] has an important role in psychological and physical health [33]. Research has revealed that marital problems are most often associated with depression [22]; [27] and anxiety disorders [9]. On the contrary, a strong marital adjustment can serve as a buffer to the negativities that may arise within the family as well as to the negative effects of the experiences on the family members. The previous studies showed a positive relationship between marital adjustment and general psychological well-being that including elements like life satisfaction [4], subjective well-being [33], and happiness [21].

Larson [23] stated that resources of the social support 
have an important role on marital satisfaction. It is not possible to consider marital adjustment as a closed system in which firstly spouses and later children are included. It is supported by the fact that the results of the study in the literature indicate the predictive role of perceived social support at the level of marital adjustment [9], [14]. Social support is a hypothetical construction that emphasizes the importance of a social environment for the healthy development and adjustment of a person. The positive role of social relations and supportive behaviors in the lives of people is an accepted effect today [17]. This important effect can be considered as a buffer preventing or reducing the impact of environmental factors on both psychological and physical health, both directly and through adverse experiences [7]. Perceived social support is a subjective cognitive assessment of an individual about the relationship created with social network, especially with family and friends through trustworthiness-valuablenessCognitive assessment represents the perceived dimension of social support, whereas behavioral evaluation represents the received dimension of social support [18].

One of the important determinants of level of marital adjustment is personal characteristics [23]. In this context, researchers have shown that the value possessions of individuals can be determinative at the level of marital adjustment [22]; [25]. Values are cognitive constructs that define the priorities, preferences, and principles of individuals. Understanding the motivations and explaining the process of individual decision making have been widely studied and values have been accepted as an explanatory and predictive key role in the study of human and social dynamics [32]. Rokeach [28] defines values as "an enduring belief that a specific mode of conduct or end-state of existence is personally or socially preferable to an opposite or converse mode of conduct or end-state of existence". Theoretical discussions on the role of values in human communication and social systems and empirical research have been widely conducted in socio-psychological and sociological literature [5]. In this process, value has been used diversely in social science researches to point out various types of selective interest, pleasure, taste, preference, duty, moral necessity, desire, will, purpose, need, disgust, sympathy and many other selective inclinations [41]. According to Schwartz [31], which expresses values as goals, a single value may be dominant, and more value can play an active role.

As a result of cultural, social and economic rapid changes, it is seen that relations in marriage change, the causes of marriage problems are diversified and the incompatibility between spouses increases in our country as well as the all over the world [37]. The problem of marriage affects not only the spouses but also the children and the spouses' immediate surroundings and at the same time, the whole society structure. Therefore, it is important to identify the elements that play a role in the harmony level of marriage. In the direction of this information it is aimed to examine the predictive role of perceived social support and value variables in marital adjustment in this study. For this purpose, the following research questions were sought:

In married individuals, does value and perceived social support significantly predict marital adjustment?

\section{Methods}

\subsection{Participants}

In line with the aim of the study, the study was conducted in accordance with the relational screening model. A total of 422 (211 couples) married individuals were recruited as participants that agreed to participate voluntarily. The sample group consists of individuals with different levels of education and professions and figures.

\subsection{Measures}

\subsubsection{Value Scale}

The value scale developed by Dilmaç, Arıcak and Cesur [10] was used to determine the level of participants' values. The scale consists of 9 sub-dimensions and 39 items "Social Values", "Career Values", "Intellectual Values", "Spirituality", "Material Values", "Human Honor", "Romantic Values", "Freedom" and "Futuwwa". As the scores on the 9-point Likert Scale increase, the importance of that value increases in the life of the person. In the reliability study of the scale, Cronbach alpha coefficients were .90 for "Social Values", .80 for "Career Values", .78 for "Intellectual Values", .81 for "Spirituality", .78 for "Materialistic Values", .61 for "Human Honor", .66 for "Romantic Values", .65 for "Freedom" and .63 for "Futuwwa". In this study, the Cronbach alpha coefficients of the subscales were .90 for "Social Values", .82 for "Career Values", .80 for "Intellectual Values", .82 for "Spirituality", .72 for "Materialistic Values", .65 for "Human Honor", .68 for "Romantic Values", .71 for "Freedom" and .68 for "Futuwwa".

\subsubsection{Dyadic Adjustment Scale (DAS)}

"Dyadic Adjustment Scale" developed by Spanier [36], adapted to Turkish by Fişıloğlu and Demir [13], was used to determine marital adjustment levels of the participants. The scale consisting of 32 items has four subscales; "Dyadic Consensus", "Dyadic Satisfaction", "Affectional Expression" and "Dyadic Cohesion". Internal consistency coefficients of the adapted scale were calculated as .75 for the dyadic consensus subscale, .83 for dyadic satisfaction subscale, .80 for the affectional expression subscale, .75 for the dyadic cohesion subscale, .92 for the entire sub-dimension. In this study, internal consistency coefficients were calculated as .78 for the idea 
sub-dimension, .81 for couple satisfaction sub-dimension, .80 for the emotional expression sub-dimension, .76 for couples' affiliation sub-dimension and .89 for the entire sub-dimension.

\subsubsection{The Multidimensional Scale of Perceived Social Support (MSPSS)}

In determining the perceived social support levels of the participants, the "Multidimensional Scale of Perceived Social Support" developed by Zimet, Dahlem, Zimet and Farley [42] and adapted to Turkish by Eker, Arkar and Yaldı [11] was used. This scale, which has three subscales as "Friends Subscale", "Family Subscale" and "Significant Other Subscale", consists of 12 items. $n$ the adaptation of the scale Internal consistency coefficients were calculated as .94 for the family support subscale, .85 for the friend support subscale, .90 for the private human support subscale, and .85 for the overall scale. In this study, the internal consistency coefficients were calculated as .90 for the family support subscale, .82 for the friend support subscale, .85 for the special human support subscale, and .86 for the whole scale.

\section{Findings}

In this section descriptive statistics for variables, the results of the analysis of correlations between variables, the predictive role of values and perceived social support variables in marital adjustmen are stated.

Given the analysis results in Table 2, there was a significant positive correlation between marital adjustment and social values $(\mathrm{r}=.22, \mathrm{p}<.01)$, career values $(\mathrm{r}=.14, \mathrm{p}$ $<.01)$, intellectual values $(\mathrm{r}=.16, \mathrm{p}<.01)$, human honor $(\mathrm{r}=.12, \mathrm{p}<.05)$, romantic values $(\mathrm{r}=.22, \mathrm{p}<.01)$, futuwwa $(\mathrm{r}=.13$, p. 01$)$, perceived family support $(\mathrm{r}=.36, \mathrm{p}<.01)$, perceived friend support $(\mathrm{r}=.24, \mathrm{p}<.01)$ and perceived private human support $(\mathrm{r}=.13, \mathrm{p}<.01)$. Also, given the analysis results in Table 1, there was no significant correlation between marital adjustment and spirituality ( $\mathrm{r}$ $=.06, \mathrm{p}>.05)$, materialistic values $(\mathrm{r}=-.00, \mathrm{p}>.05)$ and freedom $(\mathrm{r}=.09, \mathrm{p}>.05)$.

Table 1. Descriptive statistical values for variables

\begin{tabular}{|c|c|c|c|c|c|c|c|c|c|c|c|c|c|}
\hline Variable & 1 & 2 & 3 & 4 & 5 & 6 & 7 & 8 & 9 & 10 & 11 & 12 & 13 \\
\hline $\mathrm{N}$ & & & & & & & & & & & & & \\
\hline Mean & 101.2 & 89.2 & 38.5 & 47.8 & 31.5 & 19.9 & 25.4 & 23.3 & 22.3 & 15.5 & 24.2 & 21.6 & 19.1 \\
\hline ss & 14.56 & 9.40 & 5.51 & 5.53 & 5.34 & 4.86 & 2.53 & 4.44 & 3.22 & 2.51 & 4.19 & 5.45 & 7.60 \\
\hline
\end{tabular}

1. 1. Marital adjustment, 2. Social values, 3. Career values, 4. Intellectual values, 5. Spirituality, 6. Material values, 7. Human dignity, 8. Romantic values, 9. Freedom, 10. Futuwwa, 11. Family 12. Friend support, 13. Significant other support

Table 2. Correlation values indicating relationships between marital adjustment, perceived social support and value variables

\begin{tabular}{|c|c|c|c|c|c|c|c|c|c|c|c|c|c|}
\hline Variable & 1 & 2 & 3 & 4 & 5 & 6 & 7 & 8 & 9 & 10 & 11 & 12 & 13 \\
\hline 1 & 1 & & & & & & & & & & & & \\
\hline 2 & $.22 * *$ & 1 & & & & & & & & & & & \\
\hline 3 & $.14^{* *}$ & $.73 * *$ & 1 & & & & & & & & & & \\
\hline 4 & $.16^{* *}$ & $.65^{* *}$ & $.77 * *$ & 1 & & & & & & & & & \\
\hline 5 & .06 & $.51 * *$ & $.50 * *$ & $.41 * *$ & 1 & & & & & & & & \\
\hline 6 & -.00 & $.32 * *$ & $.51 * *$ & $.37 * *$ & $.25 * *$ & 1 & & & & & & & \\
\hline 7 & $.12 *$ & $.60 * *$ & $.50 * *$ & $.60 * *$ & $.37 * *$ & $.12 *$ & 1 & & & & & & \\
\hline 8 & $.22 * *$ & $.41^{* *}$ & $.44 * *$ & $.43^{* *}$ & $.25 * *$ & $.26^{* *}$ & $.23 * *$ & 1 & & & & & \\
\hline 9 & .09 & $.53^{* *}$ & $.66^{* *}$ & $.55^{* *}$ & $.36 * *$ & $.76^{* *}$ & $.29 * *$ & $.34 * *$ & 1 & & & & \\
\hline 10 & $.13 * *$ & $.49 * *$ & $.55^{* *}$ & $.61 * *$ & $.41 * *$ & $.24 * *$ & $.35 * *$ & $.32 * *$ & $.39 * *$ & 1 & & & \\
\hline 11 & $.36^{* *}$ & $.21 * *$ & $.13 * *$ & $.16^{* *}$ & .06 & .04 & $.18 * *$ & $.23 * *$ & $.10 *$ & $.11^{*}$ & 1 & & \\
\hline 12 & $.24 * *$ & .09 & .04 & .05 & -.00 & .03 & .00 & .03 & .03 & -.00 & $.33^{* *}$ & 1 & \\
\hline 13 & $.13 * *$ & .06 & -.01 & .03 & -.08 & -.03 & .02 & -.05 & -.03 & -.02 & $.19 * *$ & $.50 * *$ & 1 \\
\hline
\end{tabular}

2. 1. Marital adjustment, 2. Social values, 3. Career values, 4. Intellectual values, 5. Spirituality, 6. Material values, 7. Human dignity, 8. Romantic values, 9. Freedom, 10. Futuwwa, 11. Family 12. Friend support, 13. Significant other support

$* \mathrm{p}<.05$ 
Table 3. Results of Stepwise Multiple Regression Analysis on Prediction of Perceived Social Support and Value Variables to Marital Adjustment

\begin{tabular}{|c|c|c|c|c|c|c|c|c|c|c|}
\hline Model & $\begin{array}{l}\text { Predictive } \\
\text { Variables }\end{array}$ & B & $\begin{array}{l}\text { Stan. } \\
\text { Dev. }\end{array}$ & Beta & $\mathrm{t}$ & $\mathrm{R}$ & $\mathrm{R}^{2}$ & Tol. & VIF & $\begin{array}{l}\text { Durbin- } \\
\text { Watson }\end{array}$ \\
\hline \multirow{2}{*}{1} & (Constant) & 70.581 & 3.878 & & 18.203 & \multirow{2}{*}{.36} & \multirow{2}{*}{.13} & & & \multirow{14}{*}{1.655} \\
\hline & Family support & 1.27 & .16 & .36 & $8.013^{* *}$ & & & 1.00 & 1.00 & \\
\hline \multirow{3}{*}{2} & (Constant) & 52.492 & 6.727 & & 7.803 & \multirow{3}{*}{.39} & \multirow{3}{*}{.15} & & & \\
\hline & Family support & 1.16 & .16 & .33 & $7.221 * *$ & & & .96 & 1.048 & \\
\hline & Social values & .23 & .07 & .15 & $3.272 * *$ & & & .96 & 1.048 & \\
\hline \multirow{4}{*}{3} & (Constant) & 48.936 & 6.807 & & 7.189 & \multirow{4}{*}{.41} & \multirow{4}{*}{.16} & & & \\
\hline & Family support & 1.012 & .17 & .29 & $6.046^{* *}$ & & & .859 & 1.165 & \\
\hline & Social values & .23 & .07 & .15 & $3.247 * *$ & & & .954 & 1.048 & \\
\hline & Friend support & .34 & .13 & .13 & $2.695^{* *}$ & & & .893 & 1.120 & \\
\hline \multirow{5}{*}{4} & (Constant) & 47.412 & 6.801 & & 6.971 & \multirow{5}{*}{.42} & \multirow{5}{*}{.18} & & & \\
\hline & Family support & .95 & .17 & .27 & $5.591 * *$ & & & .834 & 1.199 & \\
\hline & Social values & .16 & .07 & .10 & $2.111^{*}$ & & & .813 & 1.229 & \\
\hline & Friend support & .36 & .13 & .13 & $2.857^{* *}$ & & & .889 & 1.125 & \\
\hline & Romantic values & .38 & .16 & .12 & $2.351^{*}$ & & & .806 & 1.241 & \\
\hline \multicolumn{11}{|c|}{ Model 1: $\mathrm{F}_{(1-420)}=64.215, \mathrm{p}<.01$} \\
\hline
\end{tabular}

$* * \mathrm{p}<.01$

$* \mathrm{p}<.05$

It has been examined whether the assumptions about regression equality are met. Tolerance values for variables ranged from. 81 to 1.00 ; and variance increase factor (VIF) values ranged from 1.00 to 1.24 . Given the values, it can be said that the conditions are met. Also, given the Durbin-Watson test result, we can say that there is no auto-correlation in the model.

Considering the analysis results in Table 3, it is seen that the phased regression analysis is completed in four stages and perceived family support, social values, perceived friendship support and romantic values variables are significant predictors of marital adjustment. In the first stage, only perceived family social support explains $13 \%$ of the total variance $\left(\mathrm{R}=.36, \mathrm{R}^{2}=.13, \mathrm{~F}(1-420)=64.215\right.$, $\mathrm{p}<.01)$. In the second stage, when the social values were included in the analysis, the total variance explained increased to $15 \%\left(\mathrm{R}=.39, \mathrm{R}^{2}=.15\right.$, Model $2: \mathrm{F}(2-419)=$ $38.203, \mathrm{p}<.01)$. In the third stage, perceived friend support was included in the analysis and the total variance explained increased to $16 \%\left(\mathrm{R}=.41, \mathrm{R}^{2}=.16\right.$, Model 3: $\mathrm{F}(3-418)=28.271, \mathrm{p}<.01)$. In the fourth stage, romantic values were included in the analysis and the total variance explained increased to $18 \%\left(\mathrm{R}=.42, \mathrm{R}^{2}=.18\right.$, Model 4 : $\mathrm{F}(4-417)=22.814, \mathrm{p}<.01)$. When the regression coefficient and $t$ values are examined, it is seen that perceived family support, social values, perceived friend support and romantic variables are positive predictors of marital adjustment. In other words, marital adjustment levels of individuals increase as the levels of perceived family support, social values, perceived friend support and romantic values increase for married individuals. In addition, it is observed that the largest contributor to the $18 \%$ total variance explained for marrital adjustment comes from perceived family social support and then perceived friend social support, romantic values and social values, respectively.

\section{Discussion}

The aim of this study was to examine the predictive role of values and perceived social support variables in marital adjustment level among married individuals. The study findings showed a positive relationship between marital adjustment and social values, career values, intellectual values, human honour, romantic values, futuwwa, perceived family social support, perceived friend and social support and perceived private human support. In addition, research findings show that perceived family social support, social values, perceived friend social support, and romantic values are positive predictors of marital adjustment. As a result of this research, it can be expressed that the marital adjustment level increases as the level of perceived family social support, social values, perceived friend social support and romantic values are increased in married individuals.

Research findings show that perceived family social support and perceived friend social support are important variables that play a positive role in marital adjustment. Marriage institution is not a closed system that has no 
interaction with social environment. It is, therefore, natural that individuals' interaction with people around them, especially with family and friend, has a predictive role on individuals' marital adjustment levels. Larson [23] stated that perceived support provided by family and friends is one of the important environmental factors playing a role in marital adjustment. In collectivist cultures such as the Turkish society, family members do not ignore the problems of the other members because social support and reciprocity are important in collectivist cultures [19] and our family that is our inner group and our neighborhood are expected to show more adaptation behavior [16]. It has been observed that the people who come from the collectivist culture adopted the norms of their group as their own norms and accepted these norms [34]. When the literature is examined, there are studies carried out for different cultures and sample groups supporting research findings as expected [14]. Marital adjustment is the ability of couples to adapt to changing conditions by marriage relationship and to change according to each other in a timely manner [36]. Marriage adjustment is a dynamic process. In some cases, adaptation to new life in relation to marriage might be painful, or other factors might lead to a decrease in marital adjustment. The social support provided by the individual's family and friends can be important in removing the negative effects of marriage. Severe home-related responsibilities can cause psychological stress in married individuals [6]. Studies have reported that marital adjustment is low for working individuals who have children, especially for working women. Experiencing psychological stress due to home-related and work-related responsibilities might adversely affect marriage adaptations of individuals [3]. Graham [14] investigated the relationship between marital adjustment and social support with a total of 91 participants (47 working women and 44 working men). In the research findings, women who have children, with low levels of social support have a lower level of marital adjustment than those with high levels of social support. Perceived social support can be said to have an indirect effect, as well as a direct role in marital adjustment. When the researchers conducted with different sample groups are examined, positive social support perceived from family and friends has been found to be positively correlated with psychological experiences such as individuals' hope [38], life satisfaction [15], and psychological well-being life satisfaction [38]. Positive social support, which is perceived from friends and family and rising level of well-being, can be positively reflected in the marital adjustment level of the individual. Positive social support, which is perceived from friends and family, can be positively reflected in the marital adjustment level of the individual. In a sense, it is thought that positive psychological variables can play an intermediary role between perceived social support and marital adjustment level.
The study found that the values play role in marital adjustment. When the literature is examined, there are studies supporting the research findings on the role of value preferences in marital adjustment [22]; [25]. Values accepted by couples and spouses are vital in marriage [23]; [40]. It has been seen that marital adjustment level of social values is a significant predictor of positive direction. In the formation of a healthy marriage structure, positive communication between spouses and overcoming problems with positive solutions are important [28]. Social values are a dimension that includes courtesy, respect, tolerance, humility, benevolence, attitudes, beliefs and behaviors [10]. The current research findings will not be surprising given the fact that social values might play roles of anxiety relieving and resolving of conflict among spouses during any disagreement. Larson [23] stated that features such as anger, aggressiveness, and extreme responsiveness are personal characteristics that weaken marital adjustment. Taking into account the attitudes and behaviors that are under the roof of social values, it can be said that they are in a negative relation with the negative characteristics expressed by Larson [23]. In the present research, the other variable that has a predictive role in marital adjustment after social values is romantic values. Kublay and Oktan [21] in the survey conducted by 452 married individuals living in the province of Rize found that romantic values were a predictor of marital adjustment as it is in the current work. The romantic values include the concepts of wife/lover, pleasure/enjoyment and love [10]. It can be said that the romantic values are directly related to the marriage relation. The fact that romantic values take place in the value system of the individual can be expected to make it easier for the individual to adapt to the marriage.

\section{Conclusions}

The present research findings show that perceived family social support, social values, perceived friend social support and romantic values are positively significant predictors of marital adjustment. With this result, it can be said that the current research has some limitations. First of all, a quantitative research path was followed in the direction of the study. It is thought that the studies to be carried out by following the qualitative research method regarding the role of the variables discussed in the study in marital adjustment level will be important. Marriage adjustment is not a static situation but a dynamic process. This situation was ignored when the data were collected. Families (husband / wife) may have influenced each other while filling scales. The high level of education of parents ( $75 \%$ of higher education) may have affected the values, the type of marriage (flirting $64 \%$ and agreement $15 \%$ ) may have affected the couple adjustment and working status (82\%) may have affected perceived social support. This data may have affected the results. There is also a 
need for studies on the existence of intermediate variables that can play a role in marital adjustment and perceived social support variables. Thus, it is thought that the concept will be based on and will give a light to the work to be done to solve the problem. However, the data set of sample is limited to 422 participants who voluntarily agreed to participate in the survey. Investigating the variables studied in the study with different sample groups seems to be important in terms of the reliability of the results. In the context of the research, perceived social support resources and value systems have a predictive role in marital adjustment thus that has a great influence on the psychological and physiological health of the individual, family and society. Based on this result, it is important to be aware of the relationship between marital adjustment and social support resources and value preferences in marriage and family counseling and to draw attention to this issue.

\section{REFERENCES}

[1] Angela, L., Robustelli, B. L. \& Whisman, M. A. Marital adjustment and distress in Japan, Journal of Social and Personal Relationships, 33(7), 855-866., 2016.

[2] Aydın, A., Kahraman, N. \& Hiçdurmaz, D. Determining the levels of perceived social support and psychological well-being of nursing students, Journal of Psychiatric Nursing, 8(1), 40-47, 2017.

[3] Barnett, R. C., Brennan, R. T., Raudenbush, S. W. \& Marshall, N. L. Gender and the relationship between marital-role quality and psychological distress: A study of women and men in dual-earner couples, Psychology of Women Quarterly, 18, 105-127, 1994.

[4] Be, D., Whisman, M. A. \& Uebelacker, L. A. Prospective associations between marital adjustment and life satisfaction, Personal Relationships, 20(4), 728-739. doi: $10.1111 /$ pere. $12011,2013$.

[5] Bilsky, W. \& Schwartz, S. H. Values and personality, European Journal of Personality, 8, 163-181, 1994.

[6] Bird, C. E. Gender, household labor, and psychological distress: The impact of the amount and division of housework, Journal of Health and Social Behaviour, 40, 32-45, 1999.

[7] Cohen, S. \& Wills, T. A. Stress, social support, and the buffering hypothesis, Psychological Bulletin, 98(2), 310-357, 1985.

[8] Coltrone, S. \& Collins, R. Sociology of marriage and the family: Gender, love and property (5th edit.), Wadsworth/Thomson Learning, Chicago, 2001.

[9] Dehle, C. \& Weiss, R. L. (2002). Associations between anxiety and marital adjustment, The Journal of Psychology, 136(3), 328-338.

[10] Dilmaç, B., Arıcak, O. T. \& Cesur, S. A validity and reliability study on the development of the values scale in Turkey, Educational Sciences: Theory \& Practice, 14(5), 1661-1671, 2014.

[11] Eker, D., Arkar, H. \& Yaldı, H. Factorial structure, validity, and reliability of the multidimensional scale of perceived social support, Turkish Journal of Psychiatry, 12(1), 17-25, 2001.

[12] Erbek, E., Beştepe, E., Akar, H., Eradamlar, N. \& Alpkan, R.L. Marital adjustment, Thinking Man: The Journal of Psychiatry and Neurological Sciences, 18(1), 39-47, 2005.

[13] Fışıloğlu, H. \& Demir, A. Applicability of the dyadic adjustment scale for measurement of marital quality with Turkish couples, European Journal of Psychological Assessment, 16(3), 214-218, 2000.

[14] Graham, C. W., Fischer, J. L., Crawford, D., Fitzpatrick, J. \& Bina, K. Parental status, social support, and marital adjustment, Journal of Family Issues, 21(7), 888-905, 2000.

[15] Gümüş, H. The married individuals with perceived social support level relationship between life satisfaction and problem solving skills, Journal of Research in Education and Teaching, 4(3), 150-162, 2015.

[16] Hofstede, C. Culture's consequences: International differences in work-related values. Beverly Hills, CA: Sage. 1980

[17] House, J. S., Landis, K. R. \& Umberson, D. Social relationships and health, Science, 540-545, 1988.

[18] Kef, S. The personal networks and social supports of blind and visually impaired adolescents, Journal of Visual Impairment \& Blindness, 91, 236- 244, 1997.

[19] Kağıtçibaşi, Ç. İnsan ve insanlar [New people and people]. Evrim yayıncılik, İstanbul. 2012.

[20] Kalmykova, E. S. Psychological problems of the first years of married life. Soviet Psychology, 22 (3), 61-73. 1984.

[21] Kublay, D. \& Oktan, V. Marital adjustment: The examination in terms of value preferences and subjective happiness, Turkish Psychological Counseling and Guidance Journal, 5(44), 25-35, 2015.

[22] Kung, W. W. \& Elkin, I. Marital adjustment as a predictor of outcome in individual treatment of depression, Psychotherapy Research, 10(3), 267-278. doi: $10.1093 / \mathrm{ptr} / 10.3 .267,2000$.

[23] Larson, J. H. The great marriage, tune-up book: A proven program for evaluating and renewing your relationship, John Wiley \& Sons, West Sussex, 2002.

[24] Larson, J. H. \& Holman, T. B. Premarital predictors of marital quality and stability, Family Relations, 43(2), 228-237, 1994.

[25] Medling, J. M. \& McCarrey, M. Marital adjustment over segments of the family life cycle: The issue of spouses' value similarity, Journal of Marriage and the Family, 43(1), 195-203. doi: 10.2307/351430, 1981.

[26] Özge, Y., \& Dag, I. The relationship between marital adjustment symptoms in Women: The mediator roles of coping strategies and gender role attitudes, Turkish Journal of Psychiatry, 26(3), 181-188, 2015. 
[27] Peterson-Post, K. M., Rhoades, G. K., Stanley, S. M. \& Markman, H. J. Perceived criticism and marital adjustment predict depressive symptoms in a community sample, Behavior Therapy, 45(4), 564-575, 2014.

[28] Rokeach, M. The nature of human values, The Free Press, New York, 1973.

[29] Sabatelli, R. M. Measurement issues in marital research: A review and critique of contemporary survey instruments, Journal of Marriage and the Family, 50, 891-915, 1988.

[30] Sabatelli, R. \& Ronald, M. The marital comparison level index: A measure for assessing outcomes relative to expectations, Journal of Marriage and the Family, 46(3), 651-662, 1984.

[31] Schwartz, S. Universals in the content and structure of values: theoretical advances and empirical tests in 20 countries, In Advances In Experimental Social Psychology, Ed.; M. P. Zanna, 25,1-65, Academic Press, San Diego, 1992.

[32] Schwartz, S. H. Basic Human Values: Theory, Measurement, and Applications, http://segr-did2.fmag.unict.it/allegati/ convegno \%207-8-10-05/ schwartzpaper.pdf, 2006.

[33] Scorsolini-Comin, F. \& Dos Santos, M. A. Correlations between subjective well-being, dyadic adjustment and marital satisfaction in Brazilian married people, The Spanish Journal of Psychology, 15 (1), 166-176. doi: 10.5209/ rev SJOP. 2012. v15.n1. 37304, 2012.

[34] Shweder, R.A. ve LeVine, R.A. Culture theory: Essays on mind, self and emotion. New York: Cambridge. 1984.

[35] Smith, T. W., Traupman, E. K., Uchino, B. N. \& Berg, C. A.
Interpersonal circumflex descriptions of psychosocial risk factors for physical illness: Application to hostility, neuroticism, and marital adjustment, Journal of Personality, 78(3), 1011-1036. doi: 10.1111/j.1467-6494.2010.00641.x, 2010 .

[36] Spanier, G. B. Measuring dyadic adjustment: New scales for assessing the quality of marriage and similar dyads, Journal of Marriage and The Family, 38(1), 15-28, 1976.

[37] Şener, A. \& Terzioğlu, G. Study on some socio-economic and demographic variables and communication effect on the marital adjustment, The Journal of Family and Society, 13(4), 7-20, 2008.

[38] Tarhan, S. (2012). The prediction of hope from self-efficacy, perceived social support and personality traits. Unpublished doctoral thesis, Gazi University, Ankara, Turkey.

[39] Tezer, E. Conflicts between married partners: Perception and satisfaction, Unpublished doctoral thesis, Hacettepe University, Ankara, Turkey, 1986.

[40] Tosun, F. and Dilmaç B. Predictor relationships between values held by married individuals, resilience and conflict resolution styles: A model suggestion. Educational Sciences: Theory \& Practice. 15(4), 849-857. DOI 10.12738/estp.2015.4.2588. 2015 .

[41] Williams, R. M. Jr. Change and stability in values and value systems: A sociological perspective, M. Rokeach (Ed.), Understanding human values (pp.15-46). The Free Press, New York, 1979.

[42] Zimmet, G. D., Dahlem, N. W., Zimet, S. G. \& Farley, G. K. The Multidimensional Scale of Perceived Social Support, Journal of Personality Assessment, 52(1), 30-41, 1988.

\footnotetext{
${ }^{1}$ This study was produced from Abdullah Mert, Ph.D. thesis study entitled "Systematic Family Oriented Psycho-Education Program's Values, Perceived Social Support and Impact on Dual Harmony" in the consultancy of Assoc. Dr. Murat İskender.
} 